\title{
EFFECT OF DOLOMITE AND CHICKEN MANURE APPLICATION ON PAK CHOI (Brassica rapa chinensis) PRODUCTION AND CARBON DIOXIDE EMISSIONS IN TROPICAL PEATLANDS
}

\author{
Salampak $^{1 \#}$, Adi Jaya ${ }^{1 \# *}$, Paska Aprianto ${ }^{2}$, Susi Kresnatita ${ }^{1}$ \\ ${ }^{1}$ Faculty of Agriculture, University of Palangka Raya, Indonesia \\ ${ }^{2}$ Postgraduate Program on Natural Resources and Environmental Management, University of Palangka Raya, Indonesia \\ \# shared first authorship \\ Received - September 04, 2021; Revision - November 07, 2021; Accepted - December 28, 2021 \\ Available Online - December 30, 2021
}

DOI: http://dx.doi.org/10.18006/2021.9(6).770.780

\section{KEYWORDS}

Ameliorant

$\mathrm{CO}_{2}$ Emissions

Pak choi

Peat Soil

\begin{abstract}
The current study was aimed to determine the effect of ameliorant on Pak choi (Brassica rapa chinensis) productivity, $\mathrm{CO}_{2}$ emissions, and factors affecting the rate of $\mathrm{CO}_{2}$ emission. The study was carried out using a non-factorial completely randomized design with seven treatments. The imposed treatment are without ameliorant (control), 10, 20, 30 ton ha ${ }^{-1}$ chicken manure, 4 ton ha ${ }^{-1}$ Dolomite + Chicken Manure @ 10 ton ha ${ }^{-1}$, Dolomite 4 ton ha ${ }^{-1}+$ Chicken Manure @ 20 ton ha ${ }^{-1}$ and Dolomite 4 ton $\mathrm{ha}^{-1}+$ Chicken Manure@ 30 ton $\mathrm{ha}^{-1}$. The variables observed are the chemical properties of peat soil, fresh and dry weight of pak choi, $\mathrm{CO}_{2}$ emissions, and factors that affect $\mathrm{CO}_{2}$ emissions. The results of the study revealed that the combination of Dolomite and chicken manure has a significant effect on the studied parameters and the combination of 4 ton ha ${ }^{-1}$ dolomite +30 ton ha ${ }^{-1}$ chicken manure had the highest $\mathrm{pH}$ change (average of 6.36), highest productivity, and $\mathrm{CO}_{2}$ emission $\left(344.42 \mathrm{mg} \mathrm{cm}^{-2} \mathrm{hr}^{-1}\right.$ ). Results of the study can be concluded that Dolomite and chicken manure has a significant effect on the various growth parameters of B. rapa chinensis and the properties of the peat soil.
\end{abstract}

* Corresponding author

E-mail: adijaya@agr.upr.ac.id (Adi Jaya)

Peer review under responsibility of Journal of Experimental Biology and Agricultural Sciences.

Production and Hosting by Horizon Publisher India [HPI] (http://www.horizonpublisherindia.in/).

All rights reserved.
All the articles published by Journal of Experimental Biology and Agricultural Sciences are licensed under a Creative Commons Attribution-NonCommercial 4.0 International License Based on a work at www.jebas.org.

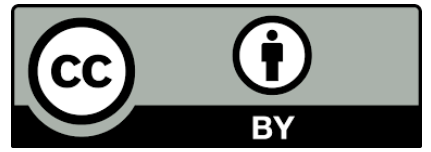




\section{Introduction}

Indonesian peatland is still unexploited for agricultural purposes but it has enough potential and it can be used for agricultural extension (Agus \& Subiksa, 2008). According to Anda et al. (2021), Indonesian peatland covered 14.1 Mha of the land area. Agricultural development in peatlands have been promoted for a long time but could not be reached to its maximum potential due to poor soil physical and chemical constraints including water dynamics, soil acidity, fertility, and low N, P, and K content. Alwi \& Hairani (2007) reported that the elements $\mathrm{K}, \mathrm{Ca}$, and $\mathrm{Mg}$ are the main limiting factors for plant growth and production on peatlands. Further, peatlands is also marginal because it is acidic in nature and poor in important nutrients and minerals that are needed to support plant growth. Along with this, the cation exchange capacity (CEC) of the peatland soil is also very high, and but base saturation is very low (Salampak, 1999).

Peat amelioration is one of the most important ways of peat quality improvement and controlling greenhouse gases emissions (Setyanto et al., 2014; Susilawati et al., 2016). Dolomite can be used as an ameliorant because it can easily absorb water and decompose, effectively improves the granulation for soil aeration, reduces $\mathrm{H}, \mathrm{Fe}, \mathrm{Al}$, and $\mathrm{Mn}$ ions, and increases the availability of $\mathrm{Ca}, \mathrm{Mg}$, and $\mathrm{P}$, and microbial activity (Utami, 2012). The dolomite application affects the soil properties and plant growth by increasing soil $\mathrm{pH}$, soil $\mathrm{CEC}$, soil retention capacity against heavy metals, P storage capacity (up to $45 \%$ ), and decrease in the solubility of heavy metals (Maftu'ah et al., 2013; Maftu'ah et al., 2014).

Koesrini et al. (2015) also suggested that lime application has a significant effect on the peatland soil $\mathrm{pH}, \mathrm{Al}-\mathrm{exch}$, and availability of nutrient elements (Siringoringo \& Siregar, 2011). Conversely, the lime application is less beneficial for nutrient balance in the soil. The use of lime will also reduce micro-elements availability, organic matter content, accelerate decomposition and lead to peat degradation. Besides, a better soil condition with the lime application will cause decomposing microorganisms (Maftu'ah et al., 2014).

Further, organic manure also has a significant effect on the management of peat soil and it is well reported that the application of chicken manure to peat soil not only increased nutrient availability but also improves soil properties. Abou El-Magd et al.(2006) and Najm et al. (2010), explained that manure can provide macro and micronutrients and improve peat soil physical and chemical properties. Elumalai \& Rengasamy (2012) suggested that the chicken manure contains higher $\mathrm{N}, \mathrm{P}$, and $\mathrm{K}$ nutrients than the other types of organic fertilizers and also found a small concentration of various plant growth regulators such as auxin, gibberellin, and cytokinins. Waseem et al. (2013) also suggested that the application of chicken manure increases the solubility of some nutrients. In general, organic fertilizers increase infiltration rate, nutrient availability, improve soil structure, water-holding capacity, bulk density, cation exchange capacity, soil $\mathrm{pH}$, and the number and activity of microorganisms (Suge et al., 2011; Taguiling, 2013). Application of chicken manure to the peatland enhance the physical properties is through a decrease in total porosity and an increase in lump density of peatlands, which increases the soil fertility, especially the level of $\mathrm{pH}, \mathrm{Ca}, \mathrm{K}, \mathrm{Mg}, \mathrm{C}$, and $\mathrm{P}$, compared to other organic materials. Manure also contains macroelements that are higher than other organic fertilizers (Mugwe et al., 2009). Taguiling (2013) suggested that the application of organic fertilizers have various limitations such as slow-released of nutrient and large quantity requirement. The weakness of manure is its ability to raise $\mathrm{pH}$ and bases content which suggested that these are required in large quantities from 2.5 - 10 ton ha ${ }^{-1}$ (Maftu'ah et al., 2014).

Organic fertilizers also affect soil biological properties, especially soil microorganisms (fungi and bacteria) that affect nutrient availability for plant growth by breaking down soil organic matter and releasing nutrients for plants. This biological activity increases soil aggregation through the secretion of a liquid adhesive that binds the soil (Taguiling, 2013). Kresnatita et al., (2013) suggested that a combination of chicken manure with fertilizers $\left(20\right.$ ton ha ${ }^{-1}+$ urea $200 \mathrm{~kg} \mathrm{~N}^{-1} \mathrm{ha}^{-1}$ ) can increase the length of corn cobs by $20.42 \%$. While the incorporation of the half-dose organic fertilizer (10 ton $\mathrm{ha}^{-1}+$ urea $200 \mathrm{~kg}$ Nha-1) increase the yield by $17.26 \%$ as compared to the recommended dosage of inorganic and organic fertilizer treatment.

The utilization of peatland for agricultural purposes is also associated with the increase the greenhouse gas emissions which cause serious environmental pollution (Maskun et al., 2021). This enhances the soil temperature and emission of $\mathrm{CO}_{2}$ by root respiration (Reddy \& Delaune, 2008). This increased temperature is associated with the reduction in groundwater and humidity, which will increase the activity of microorganisms which enhance the release of greenhouse gases such as $\mathrm{CO}_{2}, \mathrm{CH}_{4}$, and $\mathrm{N}_{2} \mathrm{O}$ (Sulistiyanto, 2004). Peatland soil has a higher moisture content, this excess humid condition enhances the activities of aerobic microorganisms level that remodel the organic matter (Unger et al., 1991; Adriany et al., 2016). Production of $\mathrm{CO}_{2}$ usually increases as the $\mathrm{pH}$ increases to $\mathrm{pH} 7$ or more than this (Luo \& Zhuo, 2010). In peat soil, the level of fungi also plays an important role in the mineralization of soil organic matter under aerobic conditions (Reddy \& Delaune, 2008).

According to Syahminar et al. (2015) adding cow manure application to peat soil has a significant effect on the increases of plant height, number of leaves, fresh weight, and dry weight of Pak Choy. The combined application of 3 tons of dolomite $\mathrm{ha}^{-1}$ and 
chicken manure 30 ton $\mathrm{ha}^{-1}$ can increase the yield of flower cabbage in peatlands (Susilawati et al., 2008; Kresnatita, 2018). This research aims to study the effect of chicken manure and its combination with dolomite ameliorant on the acidity of peat soil, the productivity of Pak Choi, $\mathrm{CO}_{2}$ emission, and the influence of environmental factors on the $\mathrm{CO}_{2}$ emission.

\section{Materials and Methods}

This study was conducted at Palangka Raya University, Indonesia For this, hemic peat soil was collected from Palangka Raya, Central Kalimantan, Indonesia regions. Required materials such as Pak choi (Brassica rapa chinensis) Nauli F1 Seeds, Dolomite, Chicken Manure, and NPK fertilizers were collected from the local markets. For estimation of $\mathrm{CO}_{2}$ emission, we need to use standard $\mathrm{CO}_{2}$, Horiba $\mathrm{pH}$ meter, $25 \mathrm{~cm}$ high chamber, and different diameters (namely 18.5, 19, 19.5, 20, 20.5, and $21 \mathrm{~cm}$ ) infrared analyzer (Fuji ZFP9GC11), FDR ML 2 Theta Probe Delta Y Device Co.

The research design used was a non-factorial Completely Random Design with 7 treatment levels and 5 replications. The imposed treatments are as follows: $\mathrm{G}_{0} \mathrm{P}_{0}=$ Without Ameliorant, $\mathrm{G}_{0} \mathrm{P}_{1}=$ Chicken Manure @ 10 ton ha ${ }^{-1}, \mathrm{G}_{0} \mathrm{P}_{2}=$ Chicken Manure 20 ton ha ${ }^{1}, \mathrm{G}_{0} \mathrm{P}_{3}=$ Chicken Manure 30 ton ha ${ }^{-1}, \mathrm{G}_{1} \mathrm{P}_{1}=$ Dolomite 4 ton ha ${ }^{1}+$ Chicken Manure 10 ton $\mathrm{ha}^{-1}, \mathrm{G}_{1} \mathrm{P}_{2}=$ Dolomite 4 ton ha ${ }^{1}+$ Chicken Manure 20 ton $\mathrm{ha}^{-1}, \mathrm{G}_{1} \mathrm{P}_{3}=$ Dolomite 4 ton ha ${ }^{1}+$ Chicken Manure 30 ton ha $^{-1}$.

\subsection{Observable Variables}

The observable variables include (i) soil $\mathrm{pH}$ was measured before and after the application of treatment and Pak Choi plant harvesting, (ii) $\mathrm{CO}_{2}$ emission was estimated at 2 times every week after planting, (iii) soil temperature in each plot of treatment was carried out twice in a week together with $\mathrm{CO}_{2}$ emission sampling, (iv) soil moisture was carried out 2 times in a week together with $\mathrm{CO}_{2}$ emission sampling, (v) fresh weight of Pak Choi was recorded after harvesting plants at 56 days, and (vi) dry weight of Pak Choi was recorded after drying in an oven at $60^{\circ} \mathrm{C}$ for 48 hours.

\subsection{Plant Cultivation}

\subsubsection{Preparation of Planting Media}

The peat soil was collected from the Palangka Raya, Central Kalimantan, Indonesia, and dried for 1 week, sieved and $5 \mathrm{~kg}$ soil filled in polybags with a size of $35 \times 40 \mathrm{~cm}$. Furthermore, prepared 35 polybags were supplemented by the predicated 7 combinations of chicken manure and dolomite.

\subsubsection{Seedlings and planting}

Healthy Pak choi seeds are sown in a $8 \times 9 \mathrm{~cm}$ polybag having peat soil media, after 14 days when plantlets were 3-4 leaves, these were transferred to poly bags that have various treatments of manure and dolomite. Standard horticultural practices such as watering, weeding, and pesticide management were carried out as required during the complete study period. Each polybag was fertilized by 2.3 g polybag $^{-1}$ of NPK fertilizer (16:16:16), this was carried out when the pak choi plants are 10 days old. Pak choi plants were harvested when the plants were 56 days old from seeding.

\subsection{Soil and Carbon Dioxide Sampling}

Peat soil samples were taken from each polybags treatment combination before planting and analyzed for $\mathrm{N}$ (Kjeldahl), $\mathrm{P}$ ( $\mathrm{P}$ Bray I,) K, Na, Ca, Mg, CEC, and Base Saturation $\left(\mathrm{NH}_{4} \mathrm{OAc} 0.1\right.$ N). $\mathrm{CO}_{2}$ emission was measured by using the static closed chamber method. Chambers used were made of stainless steel and were 20 $\mathrm{cm}$ in diameter and $25 \mathrm{~cm}$ in height. The cover of the chamber was made up of acryl and was equipped with a sample collector and pressure-regulating bag as described by Toma \& Hatano (2007). Gas measurements were carried out twice a week, for this all planted polybags were placed in the chamber on the top of the polybag of each plant. The procedure to measure $\mathrm{CO}_{2}$ emissions is as follows: Gas sample was taken using a vacuum hose of \pm 200 $\mathrm{ml}$ per plastic bag to store the gas, as a control for time zero with the chamber open. After that, the second syringe and vacuum plastic are prepared to take the gas $\mathrm{CO}_{2}$ after 6 minutes of closing the chamber. A second gas sample was collected 6 minutes after closing the chamber through the vacuum hose. Furthermore, the chamber is closed for 6 minutes, then $\mathrm{CO}_{2}$ gas is taken through the vacuum hose as much as $\pm 200 \mathrm{ml}$ per plastic bag.

The $\mathrm{CO}_{2}$ concentration of the gas samples was analyzed using a portable infrared gas analyzer (ZFP9GC11, Fuji Electric, Tokyo, Japan). First, a standard gas sample of $\mathrm{CO}_{2}$ was analyzed to calibrate the analyzer. The measurement results from the chamber are converted by calculations, which are calculated using the formula given by Katayanagi \& Ryusuke (2012):

$$
\mathrm{F}=\rho \times \mathrm{V} / \mathrm{A} \times \Delta \mathrm{c} / \Delta \mathrm{t} \times 273 /(273+\mathrm{T}) \times \alpha
$$

where: $\mathrm{F}=$ value of $\mathrm{CO} 2$ flux $\left(\mathrm{mg} \mathrm{Cm}^{-1} \mathrm{hr}^{-1}\right) ; \mathrm{V}=$ volume of chamber $\left(\mathrm{m}^{3}\right) ; \mathrm{A}=$ area of the base in the chamber $\left(\mathrm{m}^{2}\right) ; \rho=$ density of gas $\left(\mathrm{CO}_{2}\right)\left(1.977 \times 106 \mathrm{mgm}^{-1}\right) ; \Delta \mathrm{c} / \Delta \mathrm{t}=$ ratio between per material the concentration of gas in the hood over the time of extraction $\left(\mathrm{m}^{3} \mathrm{~m}^{-3} \mathrm{hr}^{-1}\right) ; \mathrm{T}=$ absolute temperature in the chamber $\left({ }^{\circ} \mathrm{C}\right) ; \alpha=$ conversion factor for $\mathrm{CO}_{2}$ to $\mathrm{C}(12 / 44)$

\subsection{Data analysis}

In this study, collected data were analyzed using normality test, homogeneity test, linearity test, heteroscedasticity test, and multicollinearity test. For One way ANOVA and orthogonal contrast test, the obtained data were analyzed for variance with the 
F test or ANOVA level of $\alpha=5 \%$. A simple linear regression analysis will follow the result of the measurement of $\mathrm{CO}_{2}$ emissions from root respiration in pak choi cultivation. The simple regression equation is obtained by the form: $\mathrm{Y}=\mathrm{a}+\mathrm{bX}$, where: $\mathrm{Y}$ $=\mathrm{CO}_{2}$ emissions $\mathrm{X}=$ Dry Weight of Root. Furthermore for the multiple linear regression equation is as follows: $\mathrm{Y}=\mathrm{a}+\mathrm{b} 1 \mathrm{X} 1+$ $\mathrm{b} 2 \mathrm{X} 2+\mathrm{b} 3 \mathrm{X} 3$; where $\mathrm{Y}=$ dependent variable $\left(\mathrm{CO}_{2}\right.$ emissions $)$ and $\mathrm{X} 1, \mathrm{X} 2, \mathrm{X} 3=$ Independent variables (Soil pH, Soil Temperature, Soil Moisture).

\section{Results}

\subsection{Chemical Properties of Peat Soil}

The results of soil chemical analysis before ameliorant application are shown in Table 1. The peat used as a growing medium for pak choi cultivation shows that the soil has acidic nature whilst the levels $\mathrm{K}, \mathrm{Ca}, \mathrm{Mg}, \mathrm{Na}$ elements and base saturation are classified as low. Meanwhile, the elements of Total N, P, Bray I, and CEC were classified as very high.

\subsubsection{Soil pH}

The application of ameliorant has a significant effect on the $\mathrm{pH}$ of the peat soil in all treatments used in the study. Results given in Table 2 revealed that the peat soils treated with ameliorant have higher $\mathrm{pH}$ and are significantly different than the untreated soil, while soil treated with chicken manure resulted in lower $\mathrm{pH}$ and are significantly different from the treatment of various combinations of ameliorant. The treatment having chicken manure (a) 10 ton $\mathrm{ha}^{-1}$ has lower $\mathrm{pH}$ and is significantly different than treatment containing 20 and 30 ton ha $^{-1}$ of chicken manure. While no significant difference was reported between the treatments having chicken manure @ 20 ton $\mathrm{ha}^{-1}$ and 30 ton ha ${ }^{-1}$. Similar trends have been reported in the combined application of dolomite and chicken manure and the treatment having combination 4 ton $\mathrm{ha}^{-1}$ dolomite and 10 ton ha- 1 chicken manure have significantly lower than the other two combinations i.e. 4 ton $\mathrm{ha}^{-1}$ dolomite with 20 ton ha ${ }^{-1}$ chicken manure and 4 ton ha ${ }^{-1}$ dolomite with 30 ton ha ${ }^{-1}$ of chicken manure. While the higher combinations of dolomite and

Table 1 Chemical Properties of Peat Soil Before Ameliorant Application

\begin{tabular}{|c|c|c|}
\hline Chemical Properties & Value & Criteria \\
\hline $\mathrm{pH}$ & 3.31 & Very acid \\
\hline N-Total (\%) & 0.74 & Very high \\
\hline P Bray I (ppm) & 266.27 & Very high \\
\hline $\mathrm{K}\left(\right.$ meq $\left.100 \mathrm{~g}^{-1}\right)$ & 0.20 & Low \\
\hline $\mathrm{Ca}\left(\right.$ meq $\left.100 \mathrm{~g}^{-1}\right)$ & 3.12 & Low \\
\hline $\operatorname{Mg}\left(\right.$ meq100g $\left.{ }^{-1}\right)$ & 1.26 & Fair \\
\hline $\mathrm{Na}\left(\mathrm{meq} 100 \mathrm{~g}^{-1}\right)$ & 0.19 & Low \\
\hline Base Saturation (\%) & 5.57 & Very Low \\
\hline CEC (meq100g ${ }^{-1}$ ) & 85.62 & Very high \\
\hline
\end{tabular}

Chemical Properties of peat soils as a result of Laboratory Analysis which is compared with the soil properties criteria described by Hardjowigeno (1986)

Table 2 Contrast Orthogonal Test of Peat Soil pH, plant fresh weight, plant dry weight and $\mathrm{CO}_{2}$ emission

\begin{tabular}{|c|c|c|c|c|c|c|}
\hline Coefficient & Treatment Comparison & Treatment & $\begin{array}{l}\text { Average Peat } \\
\text { Soil pH }\end{array}$ & $\begin{array}{l}\text { Average fresh } \\
\text { weight }(\mathrm{g})\end{array}$ & $\begin{array}{l}\text { Average Dry } \\
\text { weight }(\mathrm{g})\end{array}$ & $\begin{array}{c}\text { Average } \mathrm{CO}_{2} \\
\text { Emission } \\
\left(\mathrm{mg} \mathrm{cm}^{-2} \mathrm{hr}^{-1}\right)\end{array}$ \\
\hline $\mathrm{C}_{1}$ & $\begin{array}{c}\mathrm{G}_{0} \mathrm{P}_{0} \text { vs }\left(\mathrm{G}_{0} \mathrm{P}_{1}, \mathrm{G}_{0} \mathrm{P}_{2}, \mathrm{G}_{0} \mathrm{P}_{3}, \mathrm{G}_{1} \mathrm{P}_{1}, \mathrm{G}_{1} \mathrm{P}_{2},\right. \\
\left.\mathrm{G}_{1} \mathrm{P}_{3}\right)\end{array}$ & $\mathrm{G}_{0} \mathrm{P}_{0}$ & $3.4 \pm 0.07^{\mathrm{a} * *}$ & $37.28 \pm 3.32^{\mathrm{a} * *}$ & $1.88 \pm 0.73^{\mathrm{a} * *}$ & $134.47 \pm 7.25^{\mathrm{a} * *}$ \\
\hline $\mathrm{C}_{2}$ & $\left(\mathrm{G}_{0} \mathrm{P}_{1}, \mathrm{G}_{0} \mathrm{P}_{2}, \mathrm{G}_{0} \mathrm{P}_{3}\right)$ vs $\left(\mathrm{G}_{1} \mathrm{P}_{1}, \mathrm{G}_{1} \mathrm{P}_{2}, \mathrm{G}_{1} \mathrm{P}_{3}\right)$ & $\mathrm{G}_{0} \mathrm{P}_{1}$ & $4.4 \pm 0.19^{\mathrm{b} * *}$ & $42.20 \pm 3.90^{\mathrm{b} * *}$ & $2.80 \pm 0.17^{\mathrm{b}} * *$ & $169.67 \pm 10.61^{\mathrm{b} * *}$ \\
\hline $\mathrm{C}_{3}$ & $\mathrm{G}_{0} \mathrm{P}_{1}$ vs $\left(\mathrm{G}_{0} \mathrm{P}_{2}, \mathrm{G}_{0} \mathrm{P}_{3}\right)$ & $\mathrm{G}_{0} \mathrm{P}_{2}$ & $5.5 \pm 0.77^{\mathrm{c} * *}$ & $45.26 \pm 2.09^{\mathrm{c} * *}$ & $3.86 \pm 0.63^{\mathrm{c} * *}$ & $213.82 \pm 9.52^{\mathrm{c} * *}$ \\
\hline $\mathrm{C}_{4}$ & $\mathrm{G}_{0} \mathrm{P}_{2}$ vs $\mathrm{G}_{0} \mathrm{P}_{3}$ & $\mathrm{G}_{0} \mathrm{P}_{3}$ & $5.7 \pm 0.91^{\mathrm{c} *}$ & $54.24 \pm 6.07^{\mathrm{d} * *}$ & $4.84 \pm 0.72^{\mathrm{d} * *}$ & $241.98 \pm 12.50^{\mathrm{d} * *}$ \\
\hline $\mathrm{C}_{5}$ & $\mathrm{G}_{1} \mathrm{P}_{1}$ vs $\left(\mathrm{G}_{1} \mathrm{P}_{2}, \mathrm{G}_{1} \mathrm{P}_{3}\right)$ & $\mathrm{G}_{1} \mathrm{P}_{1}$ & $6.0 \pm 0.87^{\mathrm{d} *}$ & $66.24 \pm 6.32^{e_{* *}}$ & $5.84 \pm 0.91^{\mathrm{e} * *}$ & $274.21 \pm 8.73^{\mathrm{e}_{* *}}$ \\
\hline $\mathrm{C}_{6}$ & $\mathrm{G}_{1} \mathrm{P}_{2}$ vs $\mathrm{G}_{1} \mathrm{P}_{3}$ & $\mathrm{G}_{1} \mathrm{P}_{2}$ & $6.2 \pm 0.26^{\mathrm{d} *}$ & $75.28 \pm 4.35^{\mathrm{f}_{* *}}$ & $6.88 \pm 1.27^{\mathrm{f} * *}$ & $309.99 \pm 16.32^{\mathrm{f} * *}$ \\
\hline $\mathrm{C}_{7}$ & & $\mathrm{G}_{1} \mathrm{P}_{3}$ & $6.3 \pm 0.19^{\mathrm{d}}$ & $78.16 \pm 4.19^{\mathrm{g} * *}$ & $7.76 \pm 1.86^{\mathrm{g} * *}$ & $344.42 \pm 14.63^{g * *}$ \\
\hline
\end{tabular}

Values are average of five replicates; Mean \pm SE value followed by the different letters in a same vertical column are significantly different according to the $5 \%$ Orthogonal Contrast test, $* *$ significantly different, $*$ nonsignificant.

Journal of Experimental Biology and Agricultural Sciences http://www.jebas.org 
chicken manure are not significantly different from each other but are superior to untreated control.

\subsubsection{Fresh Weight of Pak choi}

The results related to the analysis of variance showed a significant difference in fresh weight in the Pak choi plants and the result of the Contrast Orthogonal Test are presented in Table 2. Table 2 shows that plants with ameliorants have a higher fresh weight and are significantly different than those without ameliorants. Although plants treated with only chicken manure produced significantly higher fresh weight as compared to the untreated treatments but they produced lower fresh weight which is not significantly different compared to the combination treatment of ameliorants. The fresh weight of pak choi increased with the increasing dose of chicken manure and this was reported lower in the plant treated with 10 ton $\mathrm{ha}^{-1}$ (37.28 grams) and this was significantly different than the plant treated with 20 ton $\mathrm{ha}^{-1}$ and 30 ton $\mathrm{ha}^{-1}$ of chicken manure. Similar trends have been reported in the combined application of dolomite and plants treated by 4 ton $\mathrm{ha}^{-1}$ dolomite and 10 ton ha $^{-1}$ chicken manure have a lower fresh weight and it was increased with the increasing concentration of chicken manure and it was reported highest in the plant treated by the combination of 4 ton ha ${ }^{-1}$ dolomite with 30 ton ha ${ }^{-1}$ of chicken manure (78.16 grams).

\subsubsection{Dry Weight}

Table 2 suggested that results related to the pak choi plant dry weight are similar to the fresh weight and the plants treated with ameliorants have significantly higher dry weight as compared to the untreated plants (1.88 grams). Plants treated with only chicken manure produced significantly lower dry weight as compared to the plant treated with various ameliorant combinations and in treated plants, the plant treated by 10 ton $\mathrm{ha}^{-1}$ had the lowest dry weight, while it was reported highest in the plant treated by the combined application of 4 ton ha ${ }^{-1}$ dolomite and 30 ton ha ${ }^{-1}$ chicken manure (7.76 grams)

\subsubsection{Carbon Dioxide Emissions}

The results of $\mathrm{CO}_{2}$ emission by the plant grown in peat soil and treated by ameliorant treatments were significantly different in all the applied doses (Table 2). Results of the study revealed a significant effect of ameliorant application on $\mathrm{CO}_{2}$ emissions and it was significantly different than the untreated plants. The application of chicken manure resulted in lower $\mathrm{CO}_{2}$ emissions and is very significantly different than the treatment of various ameliorant combinations. Among the various tested treatments highest $\mathrm{CO}_{2}$ emission ( $344.42 \mathrm{mg} \mathrm{Cm}^{-1} \mathrm{hr}^{-1}$ ) was reported from the plants treated by $\mathrm{G}_{1} \mathrm{P}_{3}$ combinations $\left(4\right.$ ton $\mathrm{ha}^{-1}$ dolomite and 30 ton $\mathrm{ha}^{-1}$ chicken manure) while the lowest $\mathrm{CO}_{2}$ emission (134.47 $\mathrm{mg} \mathrm{Cm}-2 \mathrm{hr}-1)$ was reported by the untreated plants $\left(\mathrm{G}_{0} \mathrm{P}_{0}\right)$.

\subsection{Root Simple Linear Regression Test on Carbon Dioxide Emissions}

To determine the relationship between root respiration and the amount of $\mathrm{CO}_{2}$ emission in $\mathrm{Pak}$ choi cultivation a simple regression test was carried out. The effect of root respiration on the amount of $\mathrm{CO}_{2}$ emissions at the study location is summarized in Table 3.

Table 3 Root Simple Linear Regression Test on Carbon Dioxide Emissions

\begin{tabular}{|ccccc|}
\hline \multirow{2}{*}{ Variable $(\mathrm{Y})$} & Variable $(\mathrm{X})$ & Regression Coefficient & Significance & Note \\
\hline \multirow{3}{*}{$\mathrm{CO}_{2}$ Emission } & Constanta & 102.27 & 0.00 & $\mathrm{~s}$ \\
\cline { 2 - 5 } & Dry root weight & 53.038 & 0.00 & $\mathrm{~s}$ \\
\cline { 2 - 5 } & $\mathrm{R}=0.97$ & & Very strong and Positive \\
\hline
\end{tabular}

Note: s: significant

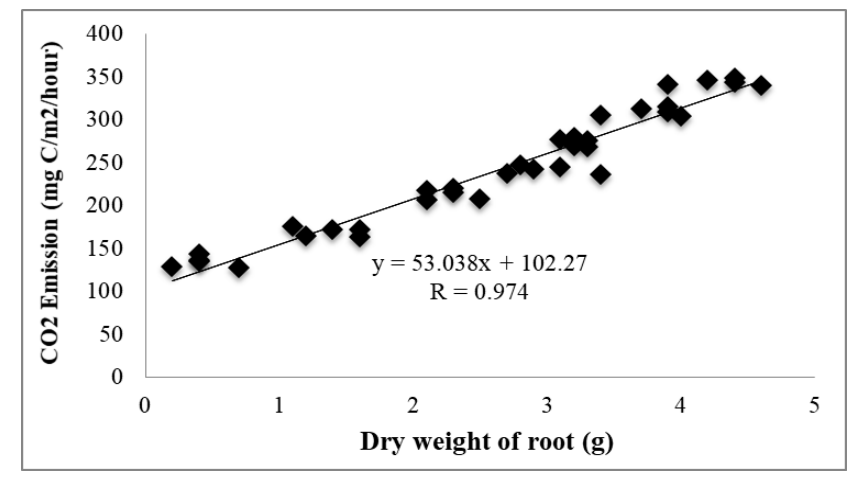

Figure 1 Scatter plot representation of the effect of Pak choi's root respiration on the $\mathrm{CO}_{2}$ Emissions

Journal of Experimental Biology and Agricultural Sciences

http://www.jebas.org 
In current study, the developed simple linear regression equation is as follows: $\mathrm{Y}=53.038 \mathrm{X}+102.267$. The regression coefficient value (constant) is 102.27 and the significance value is smaller than alpha 0.05 , thus it can be interpreted that the constant value (Y) is significantly affected by root respiration (X). The root respiration regression coefficient $(\mathrm{X})$ value is 53.038 with a smaller significance level value than alpha 0.05 , thus it can be interpreted that the root variable $(\mathrm{X})$ has a significant effect on carbon dioxide emissions $(\mathrm{Y})$ while the $\mathrm{R}$-value is 0.97 and this value suggested that the root respiration variable has a very strong correlation with carbon dioxide gas emissions. Results of the root simple linear regression test suggested that there is a strong and positive relationship between the two variables with the intention that if respiration increases, carbon dioxide emissions also increase (Figure 1).

\subsection{Influence of Various Factors on the Pattern of $\mathrm{CO}$ Emission}

The pattern of the $\mathrm{CO}_{2}$ emissions during the pak choi cultivation was also influenced by various environmental factors such as soil $\mathrm{pH}$, soil temperature, soil moisture (Figure 2; Table 4).

From the results given in figure 2 , it can be concluded that the highest $\mathrm{CO}_{2}$ emission occurred on August 30, 2020, at $431.68 \mathrm{mg}$ $\mathrm{Cm}^{-1} \mathrm{hr}^{-1}$ while the lowest was on July 31,2020 , at $56.72 \mathrm{mg} \mathrm{Cm}^{-1}$ $\mathrm{hr}^{-1}$. The multiple linear regression test was carried out to determine the magnitude of the influence and the form of environmental factors relationship (such as soil $\mathrm{pH}$, soil temperature, and soil moisture) against the dependent variable ( $\mathrm{CO}_{2}$ emissions). The effects of soil $\mathrm{pH}$, soil temperature, and soil moisture on $\mathrm{CO}_{2}$ emissions have been summarized in Table 4 .

From the results of multiple linear regression analysis, the obtained multiple linear regression equation is as follows: $\mathrm{Y}=85.04+5.46$ $(\mathrm{X} 1)+19.31(\mathrm{X} 2)-13.08$ (X3). From the multiple linear regression equation, it can be interpreted that the coefficient value for the independent variable soil $\mathrm{pH}$ (X1) is positive at 5.46 (X1), it also indicates by assuming the neglect of other independent variables, and suggested that if the soil $\mathrm{pH}$ variable increases by 1 then it can increase the $\mathrm{CO}_{2}$ emissions by $5.46 \mathrm{mg} \mathrm{Cm}^{-1} \mathrm{hr}^{-1}$. Furthermore, the coefficient value for the soil temperature (X2) is positive at 19.31, which also assumes the neglect of other independent variables, and suggested that if the soil temperature variable increases by $1{ }^{\circ} \mathrm{C}$, it can increase in $\mathrm{CO}_{2}$ emissions by $19.31 \mathrm{mg} \mathrm{Cm}^{-1} \mathrm{hr}^{-1}$. The coefficient value for soil moisture (X3) has a negative value of -13.08 , which indicates that assuming the neglect of other independent variables, and if the soil moisture variable increases by $1 \%$, it will affect the reduction in $\mathrm{CO}_{2}$ emissions by $13.08 \mathrm{mg} \mathrm{Cm}^{-1} \mathrm{hr}^{-1}$. The $\mathrm{R} 2$ value is 0.99 which means that soil $\mathrm{pH}$, soil temperature, and soil moisture partially affected the $\mathrm{CO} 2$ emission variable by $99 \%$, while the remaining $1 \%$ is influenced by other factors which were not examined in this

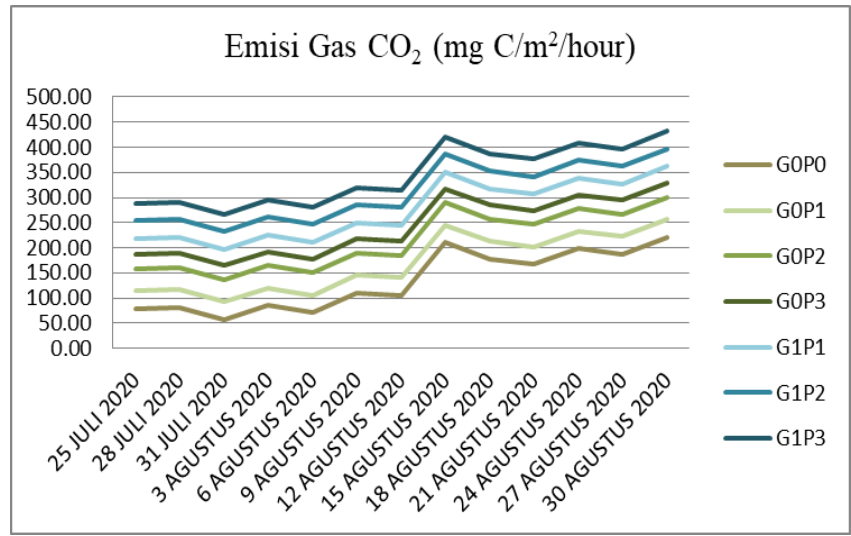

Figure 2 Pattern of $\mathrm{CO}_{2}$ Emission during Pak choi Cultivation

Table 4 Multiple Linear Regression Test for the influence of Soil pH, soil temperature and soil moisture against $\mathrm{CO}_{2}$ emissions

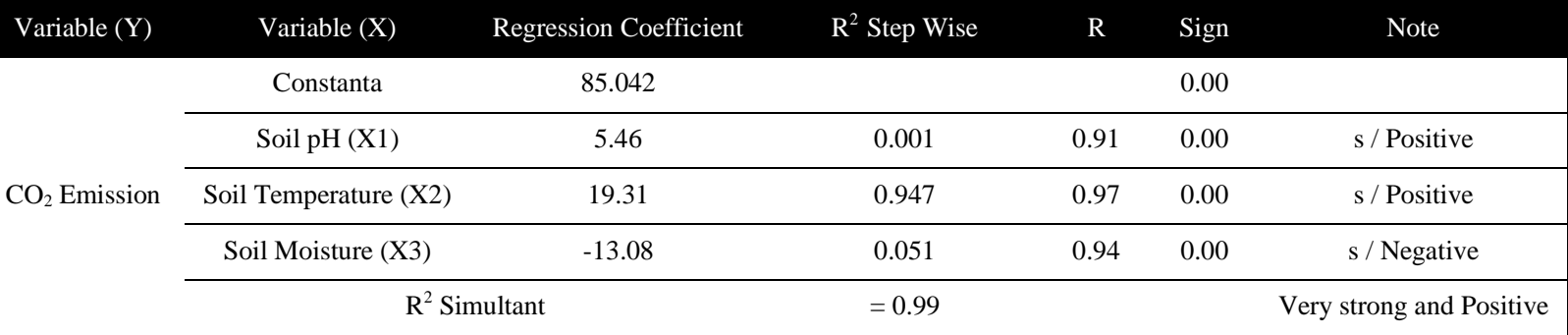

Note: s : significant, ns : non significant

Journal of Experimental Biology and Agricultural Sciences http://www.jebas.org 


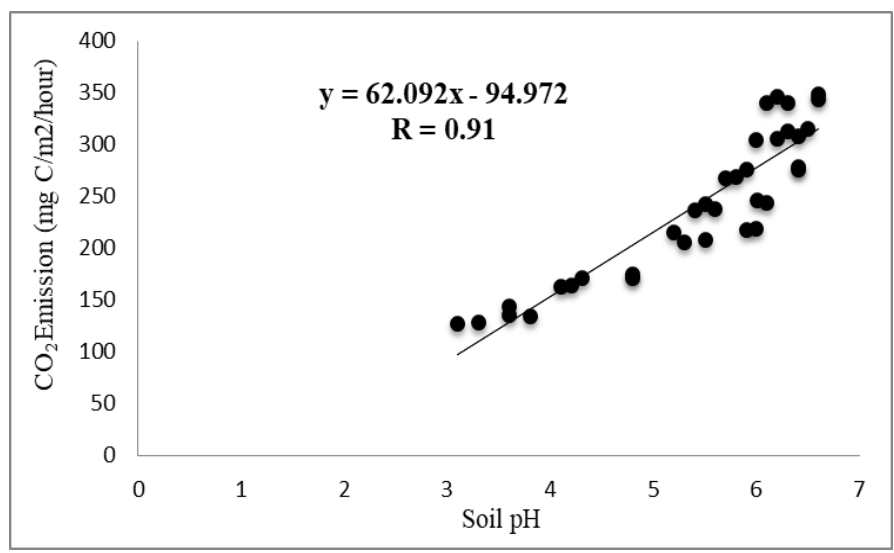

Figure 3 Effect of Soil $\mathrm{pH}$ on $\mathrm{CO}_{2}$ Emissions
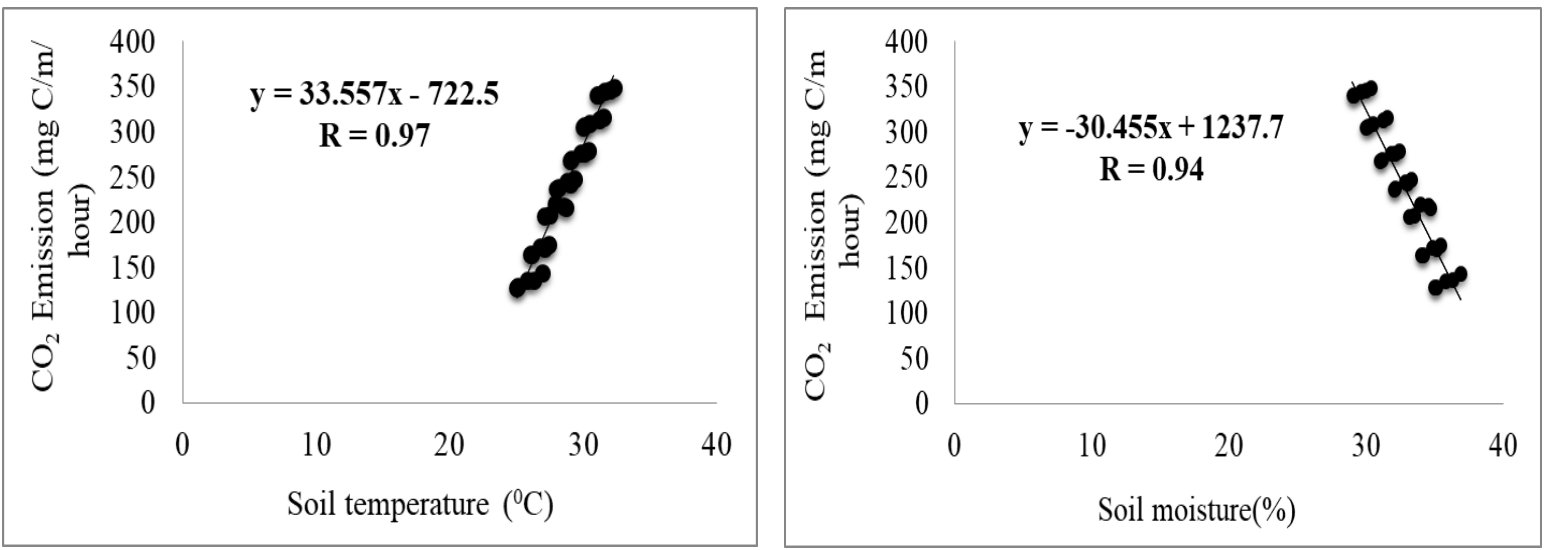

Figure 4 Effect of Soil Temperature and Humidity on $\mathrm{CO}_{2}$ Emissions

research environment. Results presented in table 4, suggested a relationship between the soil $\mathrm{pH}$, soil temperature, and soil moisture $(\mathrm{X})$ and on the $\mathrm{CO}_{2}$ emission $(\mathrm{Y})$ and this can be summarized in figure 3 . The variable soil $\mathrm{pH}$ shows a significance value less than alpha 0.05 , thus it can be interpreted that there is a relationship between these two variables. With the R-value of 0.91 , the soil $\mathrm{pH}$ variable showed a very strong correlation with carbon dioxide gas emissions (Figure 3 ).

The soil temperature also shows a significance value less than alpha 0.05 , thus it can be interpreted that there is a relationship between these two variables. To see the level of relationship Rvalue was estimated and it was reported 0.97 , which means that the soil temperature variable has a strong positive correlation with carbon dioxide gas emissions (Figure 4, left). Soil moisture showed a significance value less than alpha 0.05 , thus it can be interpreted that there is a relationship between these two variables. The $\mathrm{R}$-value of this relationship was reported as 0.94 , which represents a strong negative correlation between carbon dioxide gas emissions and soil moisture (Figure 4, right).

\section{Discussion}

\subsection{Chemical Properties of Peat Soil}

The peat soil used as a growing medium for the cultivation of Pak choi plants has acidic nature $(\mathrm{pH} 3.13)$, low level of $\mathrm{K}(0.20$ meq $100 \mathrm{~g}^{-1}$ of soil), Ca (3.32 meq100 $\mathrm{g}^{-1}$ of soil), $\mathrm{Mg}(1.26$ meq $100 \mathrm{~g}^{-1}$ of soil $), \mathrm{Na}\left(0.19\right.$ meq $100 \mathrm{~g}^{-1}$ of soil $)$ and base saturation $(5.57 \%)$ were reported. While the level of $\mathrm{N}(0.74 \%)$, P Bray I (266.67ppm), and CEC (85.62 meq100g-1of soil) in peat soil were classified as very high (Table 1). According to Sutedjo et al. (1991), the acidity of peat soil might be associated with the higher content of organic acids, slow decomposition of organic matter under anaerobic conditions, and the formation of phenolic and carboxylate compounds. Results of the current study are also in line with Limin (1998) which states that although organic matter's weathering produces nutrients for plants but it also produces organic acids which enhance the soil acidity and negatively affect plant growth. The high CEC in peat soils is associated with the high content of organic matter composed of lignin fractions and humic compounds. This is 
similar to Setiawan (1991), those who proposed that the higher lignin fraction and humic compounds in peat soils have the higher the CEC value. Peat soil has a very low content of alkaline cations such as $\mathrm{Ca}, \mathrm{Mg}, \mathrm{K}$, and $\mathrm{Na}$, especially in thick peat. The low content of bases is accompanied by a high value of cation exchange capacity (CEC) which causes the low availability of the bases. Similar results were reported by Leiwakabessy (1978) and suggested that the low content of bases in peat is closely related to its formation process and is highly influenced by rainwater. Peat soil has a high content of $\mathrm{N}$ elements, which is associated with the presence of higher organic material. Similarly, Sajarwan (1998) reported a higher concentration of the total $\mathrm{N}$ content in peat soils and it is relatively very higher $(0.3-2.1 \%)$ in some areas of Indonesia. Similarly higher P Bray concentration was reported from the collected peat soil samples. Although results of soil analysis suggested the higher content of total $\mathrm{N}$ and $\mathrm{P}$ Bray but these are available in organic $(\mathrm{N})$ and metal cations $(\mathrm{P})$ form the availability of these two for plants nutrition is generally low. So the higher concentration $\mathrm{N}$ and $\mathrm{P}$ elements are not a guarantee of the availability of these macronutrients for plants. Similarly, Salampak (1999) stated that the CEC of peat soil is high, but low base saturation (BS) reduces the peat soil $\mathrm{pH}$ and it becomes acidic and the amount of fertilizer applied in this soil is relatively difficult to absorb by plants.

\subsection{Effect of Ameliorants on Peat Soil pH}

Data from orthogonal contrast test at a confidence level of $5 \%$ revealed that increasing doses of chicken manure (10, 20, and 30 ton $\mathrm{ha}^{-1}$ ) and its combination with dolomite (@ 4 ton ha ${ }^{-1}$ ) have a significant effect on increasing the $\mathrm{pH}$ of peat soil (Table 2). These results are in agreement with the findings of Maryati et al. (2014) those who suggested that the application of organic material from oil palm empty bunch results in the increase of $\mathrm{pH}$. Although chicken manure has neutral $\mathrm{pH}$ but during decomposition of chicken manure various organic compounds such as carboxyl and phenolic groups are released, these organic compounds bind with $\mathrm{Al}$ and $\mathrm{Fe}$, in this manner these could not contribute $\mathrm{H}^{+}$into the soil and reduce the acidity of peat soil. Dolomite also contributed to the increase of soil $\mathrm{pH}$ because it contains high $\mathrm{Ca}$ and $\mathrm{Mg}$ elements which can shift the position of $\mathrm{H}^{+}$on the surface of the colloid and help in the neutralizing of soil acidity (Nurhayati et al., 2014). Apart from the hydrolysis reaction dolomite can also release $\mathrm{OH}^{-}$ions, which help in the increasing peat soil $\mathrm{pH}$. These results are in agreement with the findings of Maftu'ah et al., (2013), that lime supplies $\mathrm{OH}^{-}$into the soil solution which reacts with $\mathrm{H}^{+}$and increases the soil $\mathrm{pH}$. The combination of chicken manure and dolomite is found more effective in increasing the peat soil's $\mathrm{pH}$ and these results are in agreement with the findings of Brown et al. (2007).

\subsection{Effect of Ameliorants on $\mathrm{CO}_{2}$ Emissions in Peat Soils}

Contrast orthogonal test data at the $5 \%$ confidence level showed very significant effect ameliorants on $\mathrm{CO}_{2}$ emissions, while the control treatment produced the lowest emissions (Table 2). $\mathrm{CO}_{2}$ emission in the presence of ameliorants is dose-dependent and the highest doses of ameliorant produced the highest $\mathrm{CO}_{2}$ gas. This shows that the application of ameliorant contributes to $\mathrm{CO}_{2}$ gas emissions produced by pak choi cultivation. The chicken manure application provides additional organic matter into the soil and increases the soil microbial activity resulting in the highest $\mathrm{CO}_{2}$ emissions in all treatments. These results are in agreement with the findings of Nurhayati (2013) which suggested that dolomite lime contains $\mathrm{Ca}$ and $\mathrm{Mg}$ elements which increases the release of $\mathrm{OH}^{-}$ ions, soil $\mathrm{pH}$, and microbial community which enhance the $\mathrm{CO}_{2}$ emissions (Nugroho et al., 2013). Reddy \& Delaune (2008) suggested that root respiration, soil temperature, soil moisture, oxygen availability, nitrogen, soil $\mathrm{pH}$, and interactions among these are some important factors that influence the amount of $\mathrm{CO}_{2}$ emissions are.

In this study, the highest $\mathrm{CO}_{2}$ emission was reported from the combination of dolomite and chicken manure. This might be associated with the higher organic matter releases of chicken manure and increase of soil $\mathrm{pH}$ by dolomite, these two causing the decomposition of the organic matter faster which enhance the microorganism activity in remodeling organic matter and enhance the higher $\mathrm{CO} 2$ emissions. Availability of good nutrients supports the better development of plant roots and has good respiration. This is in line with Darung (2019) that the age difference of oil palm plants has an important role in the value of $\mathrm{CO}_{2}$ emissions on peatlands, mature oil palm plants have more plant roots and microbial community compared to young plants which contribute higher $\mathrm{CO}_{2}$ emissions around the plant roots. Similar results have been reported in the case of pak choi plants and the plants treated with higher concentrations of dolomite and chicken manure have good root growth as compared to the plant treated with a lower concentration of dolomite and chicken manure. The amount of $\mathrm{CO}_{2}$ emission by pak choi plants is dependent on the respiration process and microbes' decomposition process in peat soil. These results are in agreement with the findings of Ekberg et al. (2007) which suggested that plants' respiration process is one of the contributors to carbon emissions in the oil palm agroecosystems. Soil respiration is a combined process between autotrophic respiration (root respiration) and heterotrophic respiration (peat decomposition). Root respiration activity is one of the components that play an important role in determining the value of $\mathrm{CO}_{2}$ emissions released into the atmosphere (Tian et al., 2011). This study suggested that the effect of ameliorant on $\mathrm{CO}_{2}$ emissions is inconsistent because environmental factors also play an important role in releasing $\mathrm{CO}_{2}$ emissions into the atmosphere. 


\subsection{The Effect of Environmental Factors on CO2 Emission} Patterns

Based on the multiple linear regression test, it is known that the variation of $\mathrm{CO}_{2}$ emission patterns is influenced by soil $\mathrm{pH}$, soil temperature, and soil moisture simultaneously and all variables have a very strong relationship. Increased in the soil $\mathrm{pH}$ is positively correlated to the $\mathrm{CO}_{2}$ emission and the highest $\mathrm{CO}_{2}$ flux was reported from the highest $\mathrm{pH}$ soil. Similarly, the soil temperature is also positively related to $\mathrm{CO}_{2}$ emission. While the high moisture conditions hampered the $\mathrm{CO}_{2}$ emission because higher moisture creates an aerobic environment which activates the aerobic bacteria which remodels the organic matter and reduced the $\mathrm{CO}_{2}$ emission. This is similar to Reddy \& Delaune (2008) which states the factors that influence $\mathrm{CO} 2$ emission, namely root respiration, soil temperature, soil moisture, oxygen availability, nitrogen, soil $\mathrm{pH}$, and the interactions between these factors. Further, the results of the current study are in agreement with the findings of Rumbang et al. (2009) and Jauhiainen et al. (2012) those who suggested a positive effect of various environmental factors including air temperature, soil temperature, peat characteristics such as peat $\mathrm{pH}, \mathrm{CEC}$, and microorganism activity on the average value of $\mathrm{CO}_{2}$ emissions by peatlands.

\section{Conclusion}

The result of the current study can be concluded that the application of ameliorant has a dose-dependent effect and the combined application of 4 ton $\mathrm{ha}^{-1}$ dolomite and 30 ton ha chicken manure have the highest $\mathrm{pH}$, fresh weight, dry weight, and $\mathrm{CO}_{2}$ emission. Further, various environmental factors like soil $\mathrm{pH}$, soil temperature, and soil moisture also affect $\mathrm{CO}_{2}$ emissions.

\section{References}

Abou El-Magd MM, El-Bassiony AM, Fawzy ZF (2006) Effect of Organic Manure with or Without Chemical Fertilizer on Growth, Yield and Quality of Some Varieties of Broccoli Plants. Journal of Applied Sciences Research 2 (10): 791- 798.

Adriany TA, Pramono AP, Setyanto P (2016) Pemberian Amelioran Pupuk Kandang Ayam Pada Penggunaan Lahan Gambut yang Berbeda Terhadap Emisi $\mathrm{CO}_{2}$. Jurnal Ecolab 10 (2): 49-57.

Agus F, Subiksa IGM (2008) Lahan Gambut: Potensi untuk Pertanian dan Aspek Lingkungan. Balai Penelitian Tanah dan World Agroforestry Centre (ICRAF), Bogor.

Alwi M, Hairani A (2007) Karakteristik kimia lahan gambut dangkal dan potensinya untuk pertanaman cabai dan tomat. Jurnal Agronomi Indonesia 35(1): 36-43.
Anda M, Ritung S, Suryani E, Hikmat M, Yatno E, Mulyani A, Subandiono RE (2021) Revisiting tropical peatlands in Indonesia: Semi-detailed mapping, extent and depth distribution assessment. Geoderma 402:115235.

Brown TT, Koening RT, Huggins DR, Harsh JB, Rossi RE (2007) Lime effect on soil acidity, crop yield, and aluminium chemistry in direct-seeded cropping systems. Soil Science Society American Journal 72:634-640. DOI:https://doi.org/10.2136/sssaj2007.0061.

Darung U (2019) Pengelolaan Lahan Gambut Pada Kebun Kelapa Sawit (Elaeis guineensis Jacq) Yang Berwawasan Lingkungan Minimalisasi Produksi Gas $\mathrm{CO}_{2}$. Disertasi Program Pascasarjana, Universitas Brawijaya Malang, Malang, Indonesia.

Ekberg A, Buchmann N, Gleixner G (2007) Rhizospheric influence on soil respiration and decomposition in a temperate Norway spruce stand. Soil Biology and Biochemistry 39:21032110. DOI: https://doi.org/10.1016/j.soilbio.2007.03.024.

Elumalai LK, Rengasamy R (2012) Synergistic Effect of Seaweed Manure and Bacillus sp. on Growth and Biochemical Constituents of Vigna radiata L. Journal of Biofertilizers and Biopesticide 3 (3):1-7.http://dx.doi.org/10.4172/2155-6202.1000121.

Hardjowigeno S (1986) Genesis dan Klasifikasi Tanah. Jurusan Tanah, FakultasPertanian IPB: Bogor. Retrieve from http://balittanah.litbang.pertanian.go.id/ind/dokumentasi/prosiding/ prosiding\%20gambut\%20icctf/03\%20Balingtan_Prihasto_GRK_A melioran_revisi-AW-FA.pdf.

Jauhiainen J, Hooijer A, Page SE (2012) Carbon dioxide emissions from Acacia plantation on peatland in Sumatra, Indonesia. Biogeosciences 9: 617-630.

Katayanagi N, Ryusuke $\mathrm{H}$ (2012) $\mathrm{N}_{2} \mathrm{O}$ emissions during the freezing and thawing periods from six fields in a livestock farm, southern Hokkaido, Japan. Soil Science and Plant Nutrition 58: 261-271.

Koesrini K, Anwar, Berlian E (2015) Penggunaan Kapur dan Varietas Adaptif untuk Meningkatkan Hasil Kedelai di Lahan Sulfat Masam Aktual. Berita Biologi 14 (2) : 155- 156.

Kresnatita S (2018) Rekayasa Budidaya Tanaman Kubis Bunga Melalui Sistem Tumpangsari Serta Pemberian Amelioran Pada Lahan Gambut di Kalimantan Tengah. Disertasi Program Pascasarjana, Universitas Brawijaya Malang, Malang.

Kresnatita S, Koesriharti, Santoso M (2013) Pengaruh Rabuk Organik Terhadap Pertumbuhan dan Hasil Tanaman Jagung Manis. Jurnal Indonesian Green Technology Journal 1 (3): 8-17. 
Leiwakabessy FM (1978) Sifat lahan yang tersedia pada daerah transmigrasi. Seminar Pemantapan Usaha-usaha Pembangunan di Daerah Transmigrasi oleh JTKI-PPSM.

Limin SH (1998) Residual Effect of Lime, Phospahate and Manure on Crops Commodities in Inland Peat. The University of Palangka Raya.

Luo Y, Zhuo X (2010) Soil Respiration and the Environment. Academic Press, Amsterdam, Pp. 328.

Maftu'ah E, Maas A, Syukur A, Purwanto BH (2013) Efektivitas amelioran pada lahan gambut terdegradasi untuk meningkatkan pertumbuhan dan serapan NPK tanaman jagung manis (Zea mays L. var. saccharata). Jurnal Agronomi Indonesia 41(1): 16-23.

Maftu'ah E, Noor M, Hartatik W, Nursyamsi D (2014) Pengelolaan dan Produktivitas Lahan Gambut untuk Berbagai Komoditas Tanaman. Dalam Lahan Gambut Indonesia Pembentukan, Karakteristik dan Potensi Mendukung Ketahanan Pangan, Pp. 131162.

Maryati, Nelvia, Anom E (2014) Perubahan kimia tanah sawah saat serapan hara maksimum oleh padi (Oryza sativa L.) setelah aplikasi campuran kompos tandan kosong kelapa sawit (TKKS) dengan abu boiler. Jurnal Agrotek 1(1): 1-14.

Maskun, Achmad, Naswar, Assidiq H, Bachril SN (2021) Palm oil cultivation on peatlands and its impact on increasing Indonesia's greenhouse gas emissions. In IOP Conference Series: Earth and Environmental Science, IOP Publishing 724 (1): 012092.

Mugwe J, Mugendi D, Mucheru-Muna M, Odee D, Mairura F (2009) Effect of Selected Organic Materials and Inorganic Fertilizer on the Soil Fertility of A Humic Nitisol in the Central Highlands of Kenya. Soil Use and Management 25: 434 - 440.

Najm AA, Hadi MRHS, Fazeli F, Darzi MT, Shamorady R (2010) Effect of Utilization of Organic and Inorganic Nitrogen Source on the Potato Shoots Dry Matter, Leaf Area Index and Plant Height, during Middle Stage of Growth. World Academy of Science, Engineering and Technology 4: 809-812.

Nugroho TC, Oksana, Aryanti E (2013) Analisis sifat kimia tanah gambut yang dikonversi menjadi perkebunan kelapa sawit di Kabupaten Kampar. Jurnal Agroteknologi 4 (1): 25-30.

Nurhayati (2013) Pengaruh jenis amelioran terhadap efektivitas dan infektivitas mikrob pada tanah gambut dengan kedelai sebagai tanaman indikator. Jurnal Floratek 40(6) : 124-139.
Nurhayati, Razali, Zuraidah (2014) Peran berbagai jenis bahan pembenah tanah terhadap status hara $\mathrm{P}$ dan perkembangan akar kedelai pada tanah gambut asal Sumatera Utara. Jurnal Floratek 1(9): 29-38.

Reddy KR, Delaune RD (2008) Biogeochemistry of Wetland. Science and applications. CRP Press. Taylor \& Prancis Group, Pp. 806.

Rumbang N, Radjagukguk B, Parjitno D (2009) Emisi Karbon Dioksida $\left(\mathrm{CO}_{2}\right)$ dari Beberapa Tipe Penggunaan Lahan Gambut di Kalimantan. Jurnal Ilmu Tanah dan Lingkungan 9(2): 95-102.

Sajarwan A (1998) Pengaruh Pemberian Pupuk Kandang Terhadap Laju Dekomposisi dan Perubahan Sifat Kimia Tanah Gambut Fibrist. Tesis. 133. Universitas Brawijaya. Malang.

Salampak (1999) Peningkatan Produktivitas Tanah Gambut yang Disawahkan dengan Pemberian Bahan Amelioran Tanah Mineral Berkadar Besi Tinggi. Disertasi Program Pascasarjana, Institut Pertanian Bogor, Bogor.

Setiawan HK (1991) Akibat pemampatan atas sifat sifat hidrologi gambut sehubungan dengan tingkat perombakan. Tesis Sarjana Dep. Ilmu Tanah. Fak. Pertanian. University Gadjah Mada, Yogyakarta.

Setyanto P, Sopiawati T, Adriany TA, Pramono A, Hervani A, Wihardjaka A (2014) Emisi Gas Rumah Kaca dari penggunaan lahan gambut dan pemberian bahan amelioran: Sintesis lima lokasi penelitian. In Prosiding Seminar Nasional Pengelolaan Berkelanjutan Lahan Gambut Terdegradasi untuk Mitigasi Emisi GRK dan Peningkatan Nilai Ekonomi. Badan Penelitian dan Pengembangan Pertanian. Kementerian Pertanian Pp. 45-61.

Siringoringo HH, Siregar CA (2011) Pengaruh Aplikasi Arang terhadap Pertumbuhan Awal Michelia montana Blume dan Perubahan Sifat Kesuburan Tanah pada Tipe Tanah Latosol. Jumal Penelitian Hutan dan Konservasi Alam 8 (1): 65- 85.

Suge JK, Omunyin ME, Omami EN (2011) Effect of Organic and Inorganic Sources of Fertilizer on Growth, Yield and Fruit Quality of Eggplant (Solanum melongena L). Archives of Applied Science Research 3 (6):470-479.

Sulistiyanto Y (2004) Nutrient Dynamic in Different Sub-Type of Peat Swamp Forest in Central Kalimantan, Indonesia. $\mathrm{PhD}$ Dissertation submitted to the University of Nottingham-United Kingdom.

Susilawati HL, Hendri J, Nursyamsi D, Setyanto P (2008) Pengaruh Pemberian Bahan Amelioran Terhadap Fluks $\mathrm{CO}_{2} \mathrm{Pada}$ 
Pertanaman Kelapa Sawit Tanah Gambut Di Perkebunan Rakyat Kabupaten Muara Jambi Propinsi Jambi. Jambi, Indonesia.

Susilawati HL, Setyanto P, Ariani M, Hervani A, Inubushi K (2016) Influence of water depth and soil amelioration on greenhouse gas emissions from peat soil columns. Soil Science and Plant Nutrition 62(1): 57-68.

Sutedjo MM, Kartasapoetra AG, Sastromodjo RS (1991) Mikrobiologi tanah. PT Rineka Cipta, Jakarta.

Syahminar, Ali J, Cik Z (2015) Respon Pertumbuhan Dan Hasil Tanaman Pakchoy (Brassica chinensis L) Terhadap Penggunaan Beberapa Bahan Amelioran Pada Media Gambut di Polibag. Jurnal Pertanian Tropik 2 (3): 275- 285.

Taguiling MALG (2013) Quality Improvement of Organíc Compost Using Green Biomass. European Scientific Journal 9 (36): 319-341.

Tian D, Wang G, Peng Y, Yan W, Fang X, Zhu F, Chen X (2011) Contribution of autotrophic and heterotrophic respiration to Soil
$\mathrm{CO}_{2}$ efflux in Chinese fir plantations. Australian Journal of Botany 59: $26-31$

Toma Y, Hatano R (2007) Effect of crop residue C:N ratio on $\mathrm{N}_{2} \mathrm{O}$ emissions from Gray Lowland soil in Mikasa, Hokkaido, Japan: Original article. Soil Science and Plant Nutrition 53: 198-205.

Unger PW, Stewart BA, Parr JF, Singh RP (1991) Crop residue management and tillage methods for conserving soil and water in semi arid regions. Soil and Tillage Research 20: 219-240.

Utami H (2012) Pengaruh Eletric Furnace Slag, Dolomit dan Unsur Mikro terhadap Sifat Kimia Tanah serta Pertumbuhan dan Produksi Tanaman Padi Sawah (Oryza sativa) VarietasiR 64 pada Tanah Gambut Dalam dari Kumpeh, Jambi. Skripsi. Fakultas Pertanian. Institut Pertanian Bogor.

Waseem K, Hussain A, Jilani MS, Kiran M, Ghazanfarullah, Javeria S, Hamid A (2013) Nutritional Management in Brinjal (Solanum melongena L.) Using Different Growing Media. Pakistan Journal of Science 65 (1): 21 - 25. 